\title{
Ukraine's Endeavour: Drawing Near(er) to the European Union
}

\section{Tanel Kerikmäe} Archil Chochia

For the surprise of many, it was a Ukrainian Cossack Pylyp Orlyk who composed Europe's first democratic constitution (1710), which contained the principle of separation of powers that is an essential legal and political axiom for all the European Union Member States. Ukraine, however, is not one of the Member States.

Establishing kinship between the EU and Ukraine has certainly been a long and winding road, as many controversial events have happened after 1994 when the European Union and Ukraine concluded the Partnership and Cooperation Agreement which was a first milestone for mutual interests. The year 2004 has often been described as a missed opportunity for Europe as there was a highest expectation for Ukraine becoming part of the club. Since then, the clear membership perspective has been even more unattainable due to the dramatic changes in the political regime in Kyiv, and the Russian military interventions since 2014. Ukraine is a hostage to the EU-Russian relations - and the level of constructive dialogue between Brussels and Moscow is the lowest it has ever been. In this situation, the patriots of the country have no choice but to trust their own intuition and keep building the civil society, fight with corruption and improve educational and entrepreneurial environment as much as it is possible. We will honour those who, despite setbacks in international and internal politics, tirelessly strive towards the better Ukraine, the largest county of the continent. Since the launching of the European Union's Eastern Partnership Programme $(\mathrm{EaP})$, Ukraine has been involved in intensive negotiations with the EU, concerning the country's European aspirations.

The home institution of the current journal, Tallinn Law School of the Tallinn University of Technology, has a significant history of research and project activities related to the EU-Ukraine relations. The topic was thoroughly discussed in the book on the EU's EaP initiative, issued at Tallinn Law School (see Kerikmäe \& Chochia, 2016), while the research team of school has produced several other publications in this field and in cooperation with Ukrainian partners 
at the Yaroslav Mudryi National Law University, the Taras Shevchenko National University of Kyiv, the National Academy of Legal Sciences of Ukraine, and others (see, for example, Kerikmäe et al., 2017). Furthermore, Tallinn Law School has been active in project cooperation with its Ukrainian partners, projects funded by the European Commission, the Estonian Ministry of Foreign Affairs, etc.

Following this path of our research activities, the current issue of the Baltic Journal of European Studies has been largely dedicated to the topic of EUUkraine relations and offers its readers several articles produced by prominent Ukrainian scholars working on EU-Ukraine issues. The research articles cover vital topics such as international energy security, discussed by the colleagues from the Taras Shevchenko National University of Kyiv, the EU-Ukraine Association Agreement by Professor Roman Petrov from the National University of Kyiv, reforming the constitutional regulation in Ukraine by Professor Oleksandr Petryshyn and Dr. Oleh Petryshyn from the National Academy of Legal Sciences of Ukraine, Ukraine's transition to bicameralism by Professor Vasyl Tatsiy and Professor Svitlana Serohina, as well as other related themes.

Ukraine's destiny depends predominantly on the new generation, today's students who may read the analysis in the current volume. We wish that the papers, dedicated to the country that is so essential to the whole Europe, would impart knowledge to those who will try to balance the achievable and the unachievable for the sake of a stable and peaceful region.

\section{References}

Kerikmäe, T. \& Chochia, A., eds. (2016), Political and Legal Perspectives of the EU Eastern Partnership Policy, Cham: Springer International Publishing. https://doi. org/10.1007/978-3-319-27383-9

Kerikmäe, T.; Müürsepp, P.; Särav, S. \& Chochia, A. (2017), 'Ethical lawyer or moral computer - historical and contemporary discourse on incredulity between the human and a machine,' Вісник Національної академії правових наук України, vol. 2 , no. 89 , pp. $27-42$. 